\title{
STRENGTHENING TEACHER COMPETENCY IN UTILIZING EDUCATIVE DEVICES IN PAUD SEROJA DESA ARA PAYUNG
}

\author{
Faisal $^{1 *}$, Damaiwaty Ray ${ }^{1}$, Naeklan Simbolon ${ }^{1}$, Stelly Martha Lova ${ }^{1}$ \\ ${ }^{1}$ Faculty of Education, Medan State University, Medan, Indonesia \\ *Corresponding Author: faisalpendas@gmail.com
}

\begin{abstract}
This mentoring program aims to improve teacher competency in utilizing educational teaching aids (APE) at the PAUD Seroja Desa Ara Payung. The stages of activities carried out through the mentoring program include: (1) mentoring the preparation of the Learning Implementation Plan (RPP) in PAUD, (2) mentoring on how to make educational teaching aids in PAUD, (3) mentoring how to use teaching aids in PAUD learning, (4) simulation in the form of lesson study on the use of educational teaching aids in PAUD, (5) open class/real teaching using educational teaching aids in PAUD learning, (6) monitoring and evaluation, and (7) follow-up. Based on the stages of the activities carried out, teacher competency can be improved in terms of formulation of the lesson plan, the making of educational teaching aids, and their effective use in learning in PAUD. Specific targets and outcomes generated through the mentoring program include: (1) the module for making educational teaching aids in PAUD learning, (2) educational teaching aids based on themes in PAUD learning, (3) teachers using educational teaching aids that will documented in the form of learning videos, (4) scientific publications in online ISSN journals and mass media. The method of implementing assistance is carried out through several stages, including (1) preparation, (2) implementation, (3) monitoring and evaluation, and (4) follow-up. With the method used, it is able to improve teacher competencies related to the use of educational teaching aids in the learning process effectively in PAUD.
\end{abstract}

Keywords: Educative Teaching Aids, Teacher Competence, PAUD.

\section{PLEMINIARY}

The Early Childhood Education Program (PAUD) is a coaching activity consisting of children of birth (0 years) up to five years (toddlers) conducted through education to assist physical and spiritual growth and development so that children have preparedness in further education (Article 1 point 14 of Undang-undang Number 20 of 2003). The age of PAUD is the most important time in the process of child development, which causes it, ability, awareness, social awareness, and emotional development that has developed gradually (Setyaningsih, A., Nurhidhariani, R., \& Putri, AA, 2016:1). At this time, children develop many things very quickly, their growth and development occur rapidly, both physically and mentally (Suyanto, 2005). Furthermore, the number of children at this stage has an enormous potential to optimize all aspects of their development, including their motor development. Motor skills, especially basic motor. Mastery of motoric skills is needed by children as a basis for more complex work and is useful for improving the quality of life in the future. With the maturation of motor skills in children, children will not have difficulty in moving their hands and looking after them. Various kinds of benefits obtained by children to train motor movements. In addition, many also move, children also become more independent and confident. Children increase their trust in doing things because of their physical abilities. Children who move well in motor skills usually have positive social abilities (Sulistyorini, Hardjono, \& Yuyarti, 2014:50).

Given the importance of early childhood education, which is a golden age, there is a need for accuracy in learning to hone the basic potential of students from both cognitive and affective aspects, as well as psychomotor aspects (Aliyah, Mufid, \& Wibowo, 2017:72). Referring to this statement, the determinants of the accuracy of learning in PAUD depend on the competence of the teacher. Teachers should have competent competence in creating effective learning processes in PAUD. The level of competency that is attached to the teacher is also determined by the level of educational qualifications it has.

The government through the Peraturan Menteri Pendidikan Nasional Number 16 of 2007 stipulates academic qualifications and competency standards for educators, which of course aims to maintain the quality of education in Indonesia. In PAUD education, ideally, the required academic qualifications are a minimum four (D-IV) or bachelor (S1) diploma in the field of early childhood education or psychology obtained from an accredited study program. Meanwhile, the required standard of competence includes pedagogical competence, personality competence, social competence, and professional competence. When examining the criteria set by the government, it is certainly not easy 
to become an educator in PAUD. Nevertheless, the reality in the field shows that there are still many educators in PAUD who have not met these qualifications. As a result, educators in PAUD tend to not understand the stages of growth and development of children both physically and psychologically, lack creative ideas in using learning media and playing games and as well as difficulties in designing learning activities that are in accordance with the theme (Ratnaningsih, Prihatsanti, \& Prasetyo, 2017:99).

The conditions stated above also occur in the PAUD Seroja Desa Ara Payung. In general, the teacher's educational qualifications do not meet the criteria as stated earlier. This condition certainly has an impact on the teacher's low competence, especially from the pedagogical and professional aspects. As a result, the quality of learning in the Seroja ECD Village in Ara Payung Village is relatively low, so it does not reflect the effective learning process in PAUD. In fact, to achieve the maximum and optimal learning outcomes and education of PAUD children must be supported by several technical aspects in the form of teacher competencies or skills and non-technical in the form of facilities and infrastructure needed, especially Educational Game Tools (Hendayani, 2018: 93). This statement emphasizes that the success of learning in PAUD also depends on the availability of learning media in the form of APE. The obstacles, the availability of APE in the Seroja PAUD Ara Payung Village are also still limited. Thus, in addition to the relatively low teacher competency, the availability of APE to support the effective learning process in Seroja ECD Ara Payung Village is still minimal.

Responding to the above statement, it is necessary to make efforts to improve the learning process at the PAUD Seroja Ara Payung Village. One of the efforts carried out was to assist the use of APE for teachers at the Seroja ECD Village in Ara Payung Village. This activity was carried out because of the fact that one of the causes of the lack of available learning media in the form of APE in PAUD was the inability of teachers to make and use APE in the learning process. Therefore, it is necessary to assist the use of APE in the learning process in PAUD so that teachers are expected to be able to design and create learning media in the form of APE, and use it in the learning process effectively.

Actually, the assistance regarding the use of APE in PAUD learning has been carried out by observers of education in PAUD. For example, mentoring carried out by Ratnaningsih, Prihatsanti, \& Prasetyo (2017) with the title of the activity "Training for Banyumanik Sub-District Early Childhood Education (PAUD) Cadres." In its implementation, this activity focused on improving competency teacher on social and personality aspects. While increasing competence in pedagogical and professional aspects is only a small part of the mentoring program undertaken. Furthermore, almost the same assistance was carried out by Sulistyorini, Hardjono, \& Yuyarti (2014) with the title of the activity "Training on Creating Educative Cloth Books for PAUD Teachers at the Education Office of Gajahmungkur District Semarang" and Sulastri, Rahma, \& Hakim (2017) with the title of "IbM Activity Making Educational Game Tools (APE) Friendly for PAUD Teachers in Bandung City." These two activities reflect the effectiveness of APE's use in developing teacher and student competencies. in learning in PAUD. If examined further, the two assistance programs that have been conducted have only reached the stage of making APE, while at the simulation/lesson study stage or real teaching has not been done. In this way, the teacher has been proficient at making APE but has not been able to describe the effectiveness of using APE in the learning process.

Unlike the previous assistance program, the service program was arranged starting from learning planning assistance in the form of Learning Implementation Plans (RPP), making APE, how to use APE, to learning/lesson study simulations so that teachers are not only skilled in making teaching aids educative but proficient in using it in the learning process in PAUD. Thus, the main objective of the mentoring program in the form of the use of educational teaching aids as an effective medium in learning in PAUD can really improve teacher competency which leads to increased competency of students in PAUD Seroja Desa Ara Payung.

\section{IMPLEMENTATION METHOD}

The method of implementing activities is carried out in several stages, including: (1) preparation, (2) implementation, (3) monitoring and evaluation, and (4) follow-up. In simple terms, the stages of activities can be seen in Figure 1 below. 


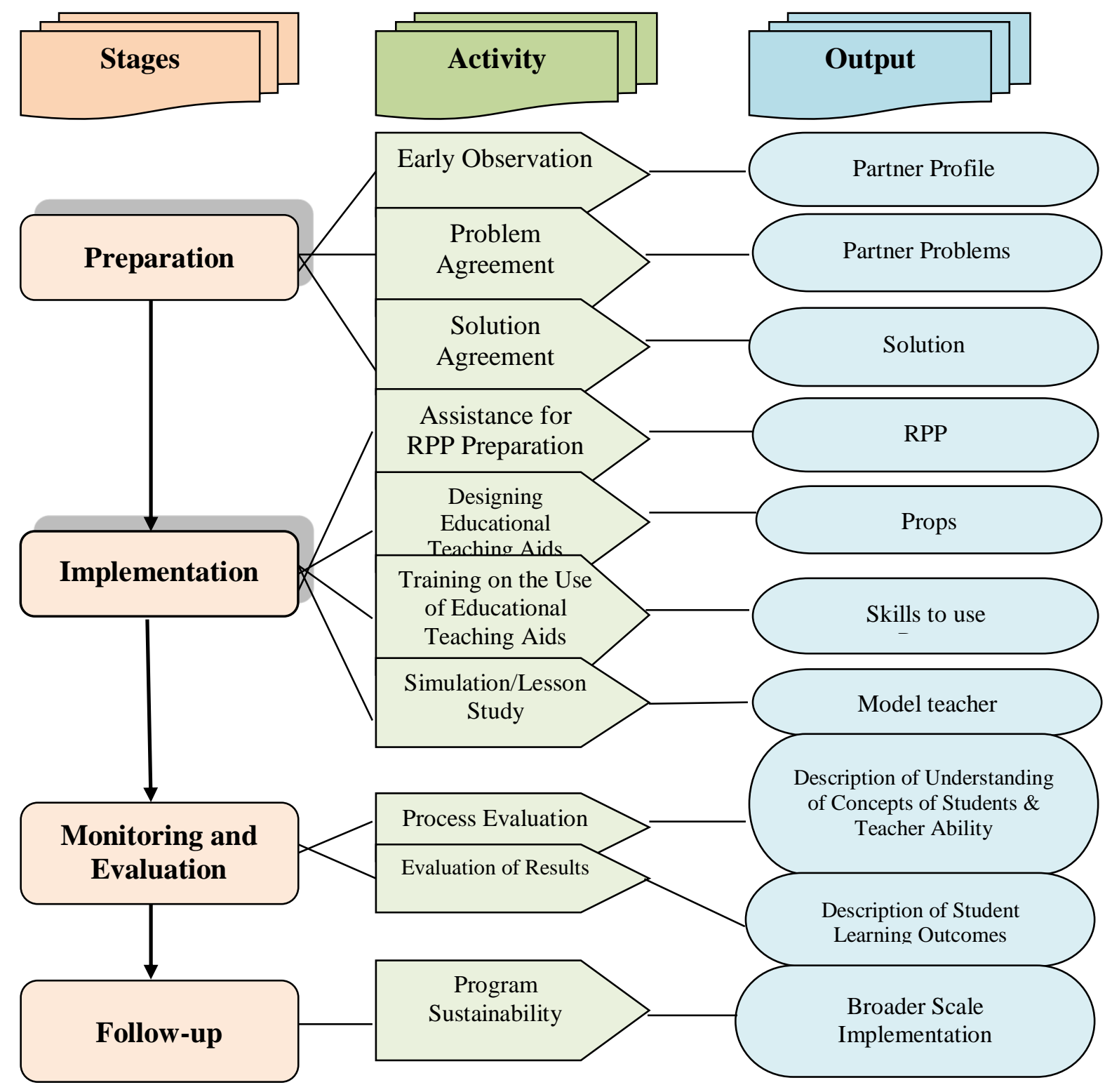

Figure 1. Implementation Method.

Referring to Figure 1, the implementation method can be explained as follows:

\subsection{Preparation}

In the preparation stage, several activities are carried out, including:

a. Preliminary observations aimed at obtaining school profiles.

b. The problem agreement faced by partners aims to determine partner priority issues that need to be given assistance.

c. Agreement on solutions to problems faced that aim to discuss methods or forms of activities in finding solutions to problems.

\subsection{Implementation}

Activities to be carried out at the implementation stage include:

a. Assistance in the preparation of Learning Implementation Plans that aims to improve the ability of teachers to design effective learning especially about the use of educational teaching aids in PAUD.

b. Designing teaching aids that aim to improve the ability of teachers to make educational teaching aids in learning in PAUD.

c. Training on the use of teaching aids that aims to improve the understanding and ability of teachers in using teaching aids that have been designed effectively in learning in PAUD. 
d. Simulation/lesson study which aims to see the teacher's ability to teach using educational teaching aids and provide input on teacher shortages during the simulation.

\subsection{Monitoring and Evaluation}

Some of the activities that will be carried out at the monitoring and evaluation stage include:

a. Process evaluation that aims to monitor and measure the effectiveness of the mentoring implementation process is seen from 2 (two) things, including: (1) description of students' understanding of the concepts taught through the use of educational teaching aids, and (2) description of levels of understanding and ease of teachers in teaching concepts using props that have been designed.

b. Results evaluation aims to see the impact and effectiveness of the use of educational teaching aids on improving student learning outcomes in PAUD.

\subsection{Follow-up}

The follow-up program is a program sustainability effort in an effort to improve the results of activities that have been obtained. This activity is carried out on a wider scale with the study and implementation of activities on other themes.

\section{RESULTS AND DISCUSSION}

\subsection{Activity Results}

In accordance with the implementation method described earlier, the implementation of the service program was carried out in 4 main stages, including preparation. implementation, monitoring and evaluation, and follow-up. The results obtained based on the 4 stages stated can be seen in the following description.

1) Preparation

Some activities carried out at the preparation stage include: determining the activity schedule, preparing the tools and materials needed, preparing assistance materials, and preparing supporting equipment, for example infocus, loudspeakers, recording media, and stationery.

\section{2) Implementation}

Mentoring activities are carried out on Thursday-Saturday, 01-03 November 2018 at PAUD Seroja Desa Ara Payung. The participants who attended the event were 30 people consisting of principals, teachers, employees, parents of students, the staff of Community Service Institutions, and students. The structured implementation of activities is divided into several stages of activities, including:

\section{a. Assistance in Preparation of Learning Implementation Plans (RPP)}

Assistance in the preparation of RPP which aims to improve the ability of teachers to design learning in PAUD based on the themes that exist in the 2013 Curriculum in PAUD. RPP preparation activities are carried out through several activities, including presentation of material on the nature of the Learning Implementation Plan (understanding, principles, and components of the Learning Implementation Plan) and the practice of drafting the RPP. The results of this activity indicate that teachers have been able to design RPPs in learning in PAUD that is integrated with the use of Educational Teaching aids in PAUD. In simple terms, the description of activities can be seen in Figure 2 below.

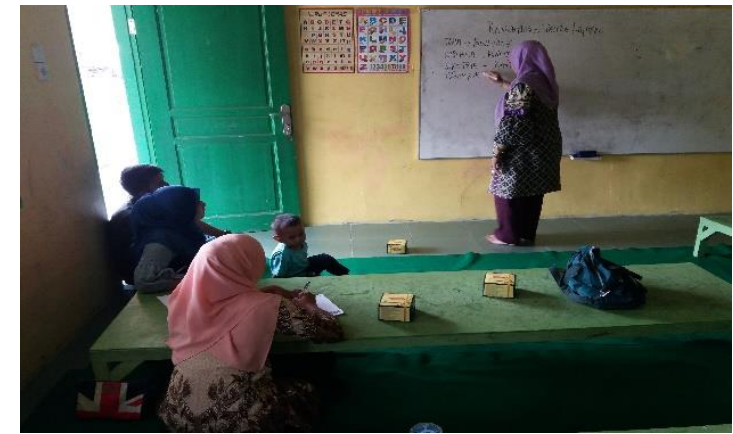

Figure 2. Assistance in Preparation of Learning Plans.

\section{b. Assistance in Designing Educational Teaching Tools (APE)}

After conducting the lesson plan activities, mentoring was designed to design educational teaching aids in PAUD. Educative Teaching aids designed are expected to be able to improve student competencies in the form of intellectual development and attitudes of students in ECD. Assistance carried out at this stage includes presentation of material on the meaning of Educational Teaching Aids and the use of Educational Teaching Aids, an explanation of the tools and materials needed, and assistance in making Educational Teaching Aids. In simple terms, the activity of designing an Educational Teaching Aid can be seen in Figure 3 below. 


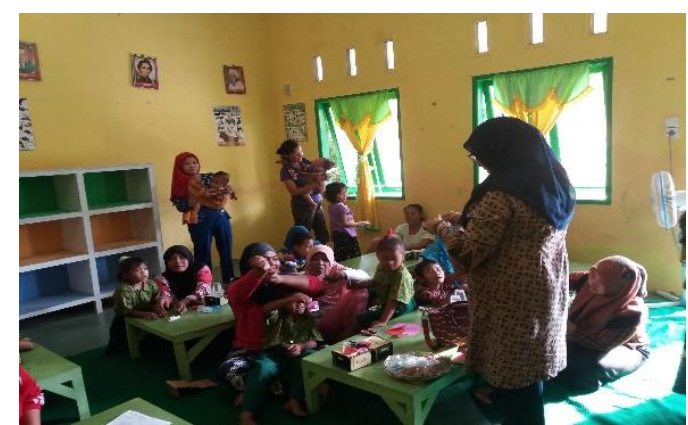

Figure 3. Mentoring in Designing Educational Teaching Aids.

\section{c. Mentoring Using Educational Teaching Aids}

The main competencies to be achieved through the mentoring program carried out are that the teacher is able to use the Educational Teaching Aid effectively in the learning process in PAUD. Efforts made at this stage are the presentation of material on how to use the Educational Teaching Tool in PAUD learning in accordance with the themes in PAUD in the 2013 Curriculum. Based on the activities carried out, the teacher can understand how to use Educational Teaching Aids in PAUD learning effectively. A simple description of the mentoring activities using Educational Teaching Aids at Seroja ECD Village in Ara Payung Village can be seen in Figure 4 below.

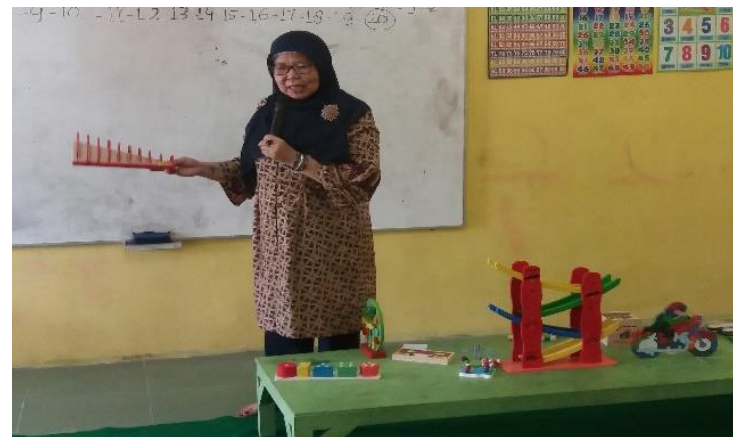

Figure 4. Assistance with the Use of Educational Teaching Aids.

\section{d. Simulation/Lesson Study Using Educational Teaching Aids}

Simulation/lesson study activities in the form of learning practices aim to see the teacher's ability to teach using Educational Teaching Aids and provide input on teacher shortages during the simulation. The teachers were asked to appear alternately in carrying out the learning process in PAUD based on the theme using the prepared Educational Teaching Aids. Through the simulations carried out, the teachers obtain valuable input and suggestions in improving teaching skills for the next stage, especially in terms of learning using Educational Teaching Tools in PAUD. Based on the assistance carried out, it can be seen that the competence and self-confidence of teachers increases in instilling concepts and attitudes towards students so that the learning objectives in accordance with the characteristics of learning in PAUD can be achieved effectively. In simple terms, the description of the learning simulation can be seen in Figure 5 below.

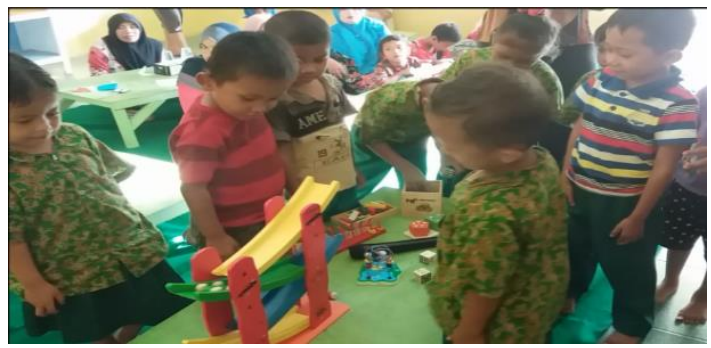

Figure 5. Learning Simulation.

\section{3) Monitoring and Evaluation}

The evaluation and reflection phase is an assessment of the success of the service program that has been implemented. Based on the results of the evaluation and reflection, an illustration of the level of achievement of the program's success and the constraints faced if the service program has not succeeded as expected. Based on observation and analysis, the success rate of the service program can be described as shown in Table 1 below. 
Table 1. Success Rate of Service Program.

\begin{tabular}{|c|l|c|l|}
\hline No & \multicolumn{1}{|c|}{ Activities } & $\begin{array}{c}\text { Percentage } \\
\text { of success }\end{array}$ & Qualification \\
\hline 1 & $\begin{array}{l}\text { The practice of } \\
\text { RPP Preparation }\end{array}$ & $85 \%$ & Very good \\
\hline 2 & Designing APE & $91 \%$ & Very good \\
\hline 3 & Using APE & $87 \%$ & Very good \\
\hline 4 & $\begin{array}{l}\text { Simulation/Lesson } \\
\text { Study }\end{array}$ & $89 \%$ & Very good \\
\hline \multicolumn{2}{|l|}{ Average } & $\mathbf{8 8 \%}$ & Very good \\
\hline
\end{tabular}

In simple terms, the description of the success of the service program can be seen in Figure 6 below.

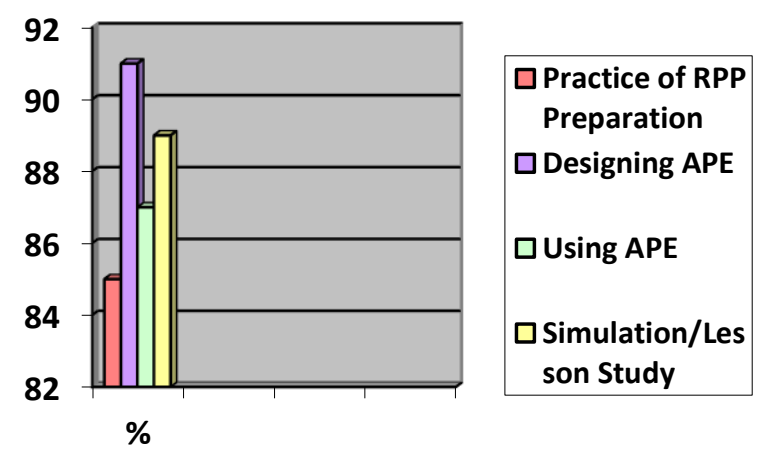

Figure 6. Success Rate of Service Program.

Based on Figure 6 above, an illustration shows that the service program carried out was obtained an average of $88 \%$ with Very Good qualifications. This means that the service program implemented very well and effectively is carried out as an effort to improve teacher competence in the use of Educational Teaching Aids as an effective medium in learning in PAUD.

\section{4) Follow-up}

Seeing the effectiveness of the service program implemented, the follow-up of the service program that has been implemented is detailed as follows.

a. Making Seroja PAUD Ara Payung Village as a target partner (School of Community Service of the Medan State University) in implementing service programs in the future.

b. Arranging the same service program on other themes in PAUD learning by following the pattern: mentoring arranging lesson plans, designing teaching aids, using teaching aids, and simulation/lesson study, and can be continued with open class activities.

c. Arrange the same service program on a broader scale, namely the level of the sub-district or district/city as a whole so that the problems of learning in PAUD can be minimized regularly.

Based on the follow-up described above, it is expected that the Community Service Institute of Medan State University will be able to develop and improve the quality of learning accompanied by increasing teacher competency, especially in designing ductile teaching aids in accordance with the characteristics of ECD learning.

\subsection{Discussion}

Firman (in Faisal, 2018:547) explains that the success of a program is characterized by the following characteristics: (a) successfully delivering participants to the specified instructional goals, (b) providing an attractive learning experience, actively involving participants so that it supports the achievement of instructional goals, and (c) has facilities that support the learning process. In addition, it was also explained that the success of the program was marked by a percentage of success of at least $\geq 75 \%$ in the good category.

Based on the opinions stated above, the success of the service program can be explained as follows.

\section{1) Develop RPP}

The percentage of success of the service program at the stage of preparing the RPP reaches $85 \%$ with Very Good qualifications. That is, the understanding and ability of teachers in preparing lesson plans related to learning in PAUD that are integrated with Educational Teaching Tools have been implemented effectively. This is indicated by the level of understanding of teachers that tend to increase and the assessment of RPP products produced when mentoring. 


\section{2) Designing Educational Teaching Aids}

The percentage obtained when mentoring designed Educational Teaching Tools reached $91 \%$ with Very Good qualifications. That is, when given assistance in designing educational teaching aids, the teacher is able to very well design it. This is indicated by the teacher's understanding of making and the level of truth of the product or educational aids produced.

\section{3) Using Educational Teaching Aids}

The follow-up of the product produced is the ability of the teacher to use it. The percentage of success of the service program at this stage reached $91 \%$ with Very Good qualifications. That is, the teacher is very good and understands very well how to use Educational Teaching aids in learning in PAUD.

\section{4) Simulation/Lesson Study}

The most important thing about this activity is the ability of teachers to use Educational Teaching Aids in real learning. The effort that can be done to measure this achievement is by conducting a simulation/lesson study on the use of educational teaching aids in learning. Through this activity, the teacher obtains input and enhances the use of Educational Teaching Aids in learning in PAUD. The percentage of success at this stage reached $89 \%$ with excellent qualifications. That is, teachers have been able to very well simulate learning using Educational Teaching Tools in PAUD learning in accordance with existing themes.

\section{CONCLUSION}

Based on the assistance program for the use of educational teaching aids in the Seroja PAUD Ara Payung Village, conclusions are obtained as follows: (1) the teacher has been able to very well arrange learning plans in the form of lesson plans based on the characteristics of learning in PAUD, (2) teachers are able to very well making various educational teaching aids in accordance with the characteristics of students in PAUD, and (3) teachers have been able to very well use educative teaching aids in the learning process in PAUD which is pursued through the level of achievement of learning/lesson study simulations with the Very Good category. Thus, the service program carried out successfully as expected in order to improve teacher competence in utilizing educational teaching aids as a manifestation of the implementation of effective learning in PAUD Seroja Ara Payung Village.

\section{THANK-YOU NOTE}

Thank you, the writer conveyed to the Community Service Institute of Medan State University which had funded and facilitated the service program carried out at the Seroja PAUD Ara Payung Village Pantai Cermin District, Serdang Bedagai Regency. Thank you also to the Village Head of Ara Payung, the Principal, and the Seroja PAUD Teacher Ara Payung Village for giving permission and supporting the implementation of the service program so that all stages of the activity were carried out as expected.

\section{REFERENCES}

Aliyah, S., Mufid, M., \& Wibowo, P. A. (2017). Pemanfaatan Sampah sebagai Alat Peraga Edukatif bagi SiswaSiswi PAUD. Journal of Dedicators Community, $l(1)$.

Faisal, F., Gandamana, A., \& Andayani, T. (2018). Penguatan Kompetensi Guru dalam Pembelajaran Tematik sebagai Upaya Optimalisasi Kurikulum 2013 di SD Kecamatan Deli Tua Kabupaten Deli Serdang. Jurnal Pengabdian Kepada Masyarakat, 24(1), 544-550.

Hendayani, E. S. (2018). Pemanfaatan Alat Permainan Edukatif (APE) dalam Pembelajaran Paud Seatap Margaluyu Kecamatan Cipatat Kabupaten Bandung Barat. Empowerment, 1(2), 92-104.

Peraturan Menteri Pendidikan Nasional Nomor 16 Tahun 2007 tentang Standar Kualifikasi Akademik dan Kompetensi Guru.

Ratnaningsih, I. R. I., Prihatsanti, U. P. U., \& Prasetyo, A. P. A. (2017). Pelatihan bagi Kader Pendidikan Anak Usia Dini (PAUD) Kecamatan Banyumanik Semarang. INFO, 17(2), 97-110.

Setyaningsih, A., Nurhidhariani, R., \& Putri, A. A. (2016). Hubungan Tingkat Pengetahuan Ibu dan Praktek Penggunaan Alat Permainan Edukatif dengan Perkembangan Motorik Kasar di PAUD Anggrek Kabupaten Pati. Jurnal Smart Keperawatan, 3(1), 1-9.

Sulastri, Y. L., Rahma, A., \& Hakim, L. L. (2017). IbM Pembuatan Alat Permainan Edukatif (APE) Ramah Anak Bagi Guru Paud di Kota Bandung. JURNAL PENGABDIAN KEPADA MASYARAKAT, 7(2), 84-91.

Sulistyorini, S., Hardjono, H., \& Yuyarti, Y. (2014). Pelatihan Menciptakan Cloth Book Educatif Bagi Guru-guru Paud Dinas Pendidikan Kecamatan Gajahmungkur Semarang. Jurnal Abdimas, 18(1).

Suyanto, S. (2005). Dasar-dasar Pendidikan Anak Usia Dini. Yogyakarta: Hikayat.

Undang-undang Nomor 20 Tahun 2003 tentang Sistem Pendidikan Nasional. 